\title{
Elisabeth Katzy, Helen Gries. "Tell Halaf (Northeast Syria) in the Achaemenid Period. A Case-Study"
}

\section{Maria Gabriella Micale}

\section{(2) OpenEdition \\ 12 Journals}

\section{Electronic version}

URL: https://journals.openedition.org/abstractairanica/52354

DOI: 10.4000/abstractairanica.52354

ISSN: 1961-960X

Publisher:

CNRS (UMR 7528 Mondes iraniens et indiens), Éditions de l'IFRI

\section{Electronic reference}

Maria Gabriella Micale, "Elisabeth Katzy, Helen Gries. "Tell Halaf (Northeast Syria) in the Achaemenid Period. A Case-Study"'!', Abstracta Iranica [Online], Volume 42-43 | 2021, document 20, Online since 15 April 2021, connection on 19 December 2022. URL: http://journals.openedition.org/abstractairanica/ 52354 ; DOI: https://doi.org/10.4000/abstractairanica.52354

This text was automatically generated on 19 December 2022.

All rights reserved 


\title{
Elisabeth Katzy, Helen Gries. “Tell Halaf (Northeast Syria) in the Achaemenid Period. A Case-Study"
}

\author{
Maria Gabriella Micale
}

\section{REFERENCES}

Elisabeth Katzy, Helen Gries. "Tell Halaf (Northeast Syria) in the Achaemenid Period. A Case-Study", Zeitschrift für Orient-Archäologie 12 (2019), p. 205-225.

1 The Authors offer a synthesis of the layers at Tell Halaf attributed to the period between the 6th-4th centuries and, thus, to the Achaemenid culture. This attribution is based on their stratigraphical position as well as to the presence of specific elements of material culture usually connected to presence of Achaemenids in residential spaces and burials. The article discusses the results of the most recent excavations on the site (campaigns 2006-2010). The Authors try first to delineate the historical and archaeological contexts of the Khabur region in this period, emphasizing how limited the archaeological documentation is from contemporary settlements in the same area and to what extent the resulting lack of knowledge may be due to the very limited number of publications that encompass possible Achaemenid layers. The article then introduces the specific archaeological context of Tell Halaf, in particular Area C. Here scanty architectural remains and five burials (phase C5) lie on top of the remains of the Late-Babylonian Governor's palace (phase C6) which was originally constructed in LateAssyrian period (phase C7). Pottery and small finds from divers contexts (not burials) are discussed separately.

2 The Authors openly speak of the great difficulty in distinguishing between the local tradition from the previous periods and possible new productions for some categories of materials such as pottery. This consideration applies to the region in general, but it may also be true in the case of Tell Halaf, where pottery analysis has faced serious 
challenges due to the current Syrian war. Comparisons for the pottery assemblage, as well as for the small finds, are drawn from different regions and often from old publications; in some cases, more recent comparative material have not been cited.The scope of the publication is explicitly defined as the identification of "archaeological markers" for this period in the Khabur region. However, because of the lack of extensive comparable data from the same region, as noted by the authors, the materials from Tell Halaf unfortunately are considered in comparative isolation. A few inconsistencies should be noted, such as the description of a "multi-phase domestic occupation" at Tell Barri (p. 206), together with evidence of an "elite material culture" (p. 217), ascribed by the Authors to a squatter occupation.

3 The few typos in the text must be attributed to the redactional mistake of the journal.

\section{AUTHORS}

\section{MARIA GABRIELLA MICALE}

Freie Universität Berlin 